\title{
Effective Management of Faecal Sludge through Co-Digestion for Biogas Generation
}

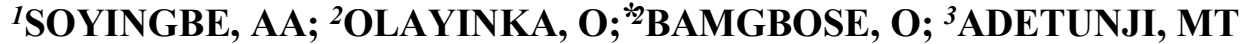

\author{
${ }^{I}$ Department of Environmental Health Sciences, Ogun State College of Health Technology, Ilese-Ijebu, Nigeria \\ ${ }^{2}$ Department of Environmental Management and Toxicology, College of Environmental Resources Management, Federal University of \\ Agriculture, Abeokuta, Nigeria \\ ${ }^{3}$ Department of Soil Science and Land Mechanization, College of Plant Science and Crop Protection, Federal University of Agriculture, \\ Abeokuta, Nigeria \\ *Corresponding Author Email: kaybam2002@gmail.com. Tel: +234 803335 3507; +234 8057475122
}

\begin{abstract}
The use of fossil fuels as primary energy source has led to global climate change and human health problems. Renewable energy resources appear to be the efficient solutions to the problems resulting from the use of fossil fuels. In this study, biogas production efficiency from faecal sludge and its combination with three feed stocks was evaluated. Three feedstock materials (cow dung, cow intestinal waste and mixed organic waste) were fed into a $2 \mathrm{~m}^{3}$ capacity digester to mix with faecal sludge for biogas production. Standard methods were used to determine chemical and biological qualities of influent and effluent slurries. The biogas produced was analyzed using multi-gas analyzer to determine the concentrations of $\mathrm{CO}, \mathrm{CO}_{2}, \mathrm{CH}_{4}$ and $\mathrm{H}_{2} \mathrm{~S}$.Methane formed major component of the biogas produced by all the substrates $(40-70 \%)$ followed by carbon dioxide $(20-30 \%)$ and $\mathrm{H}_{2} \mathrm{~S}(8-10 \%)$. The macronutrients of the bio-slurries produced ranged from Carbon (5.3 \pm $0.11-6.0 \pm 0.01 \%)$, Nitrogen $(0.36 \pm 0.1-0.46 \pm 0.1 \%)$, Phosphate $(0.11 \pm 0.02-0.24 \pm 0.11 \%)$ and Potassium $(0.1 \pm 0.01$ $-0.4 \pm 0.1 \%)$. The Carbon/Nitrogen ratio of the bio-slurries produced ranged from $12: 1$ to $15: 1$. The microbial contents of faecal sludge, only slurry had lowest total count of bacteria of $1.2 \times 10^{-2} \mathrm{cfu} / 100 \mathrm{ml}$. conclusively, co-digestion was effective in converting faecal sludge mixed the three feed stocks into pure biogas and nutrient rich bio-slurries as organic fertilizer.
\end{abstract}

\section{DOI: https://dx.doi.org/10.4314/jasem.v23i6.25}

Copyright: Copyright $(\subset) 2019$ Soyingbe et al. This is an open access article distributed under the Creative Commons Attribution License (CCL), which permits unrestricted use, distribution, and reproduction in any medium, provided the original work is properly cited.

Dates: Received: 01 April 2019; Revised: 09 May 2019; Accepted 27 June 2019

Keywords: Cow-dung, Biogas, Escherichiacoli, Faecal-sludge

The use of fossil fuels as primary energy source has led to global climate change, environmental degradation and human health problems (Adeniran et al., 2014). Renewable energy resources appear to be one of the efficient solutions to the problems resulting from the use of fossil fuels. Apart from the health implications, wastes make an environment unpleasant and unattractive. However, these wastes can be properly managed by conversion into useful and more environment-friendly forms called biogases. Biogas is a mixture of colourless, flammable gases obtained by the anaerobic digestion of plant-based organic waste materials (Abubakar, 1990). Biogas is typically made up of methane (50-70\%) carbon dioxide (30-40\%) and other trace gases (Cheremisinoff, 1980). It is generally accepted that fuel consumption of a nation is an index of its development and standard of living. There have been increases in the use of and demand for fuel in terms of transportation and power generation in many nations including Nigeria. These have so far been met in Nigeria largely from the nation's stock of fossil fuel such as crude oil, which is finite in nature. Fossil fuels are not environmentally friendly and are also expensive. The use of alternative and more environmentally-friendly energy sources such as biogas has been advocated. Biogas technology has advantages which include the following: generation of storable energy sources, production of a stabilized residue that can be used as a fertilizer, an energyefficient means of manufacturing nitrogen containing fertilizer, a process having the potential for sterilization which can reduce public health hazards from faecal pathogens, and if applied to agricultural residues, a reduction in the transfer of fungal and plant pathogens from one year's crop to the next (Bitrus, 2001). Biogas is a renewable, alternative and sustainable form of energy (Godi et al., 2013). Not only does biogas technology help to produce an alternative energy source, but it also helps in maintaining the environment and improving health conditions. The energy in plant vegetation, animals, industrial and domestic waste matter can be released in terms of a useful gas when fermented anaerobically, that is, in the absence of oxygen. The biogas formed after the decomposition of organic wastes is channeled or transported to homes for use for cooking, running engines, electrical power generation and heating, with virtually little or no pollution at all. This gas is now used in large scale in many countries (Li et al., 2009). The use of anaerobic digestion as waste-to-energy

*Corresponding Author Email: kaybam2002@gmail.com. Tel: +234803 335 3507; +234 8057475122 
technology has been employed in the treatment of different organic wastes (Lopel et al., 2004). This study focuses on biogas generation from faecal sludge through co-digestion with organic feedstock materials.

\section{MATERIALS AND METHODS}

Biogas and Bio-slurry production methods: In order to monitor the biogas and bio-slurry production, samples of three feedstock materials were used for co-digestion with faecal sludge for biogas production in the digester. The feed stock materials are; cow dung (CD), Cow intestinal waste (CIW) and mixed organic waste (MOW). The Cow dung was sourced from Federal University of Agriculture, Abeokuta (FUNAAB) Cattle cooperative farm and Cow intestinal waste was sourced from IfesowapoAsejere abattoir, Agbeloba, Abeokuta while mixed organic waste was sourced from the households and Panseke market, Abeokuta. Each of the feedstocks was replaced at the end of the retention time (time between the commencement of gas production and termination of the experiment) which is average of 30 days for each feedstock material. The feedstocks were thoroughly mixed with well water in the inlet mixing tank (Plate 1).

Each feedstock was fed into the digester and the readings taken accordingly until the retention time is reached before the next feedstock was loaded. Analysis of the effluent (slurry) was carried out with the intention to determine its suitability for farm application as organic fertilizer. Samples of the effluent slurry were taken after one month of retention in the digester. Proper stirring of the content inside the digester was carried out to ensure uniform decomposition, using a specially fabricated stirrer improvised with the digester.

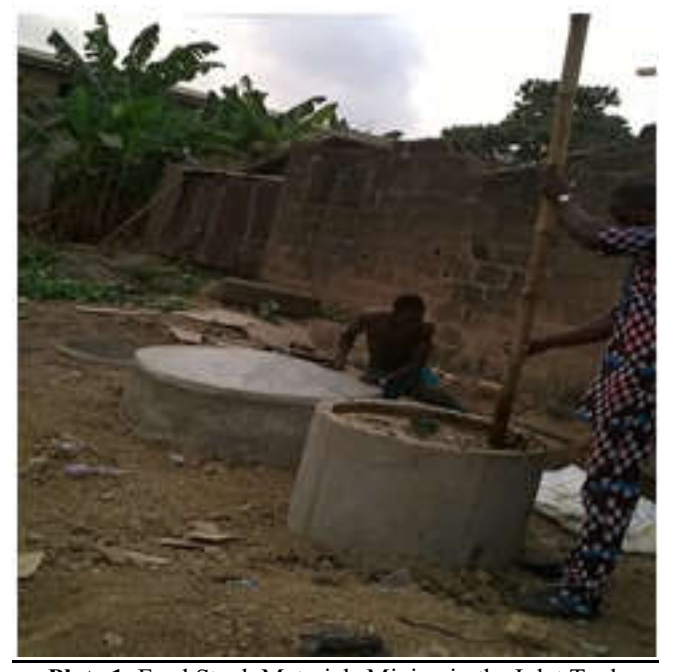

Plate 1: Feed Stock Materials Mixing in the Inlet Tank

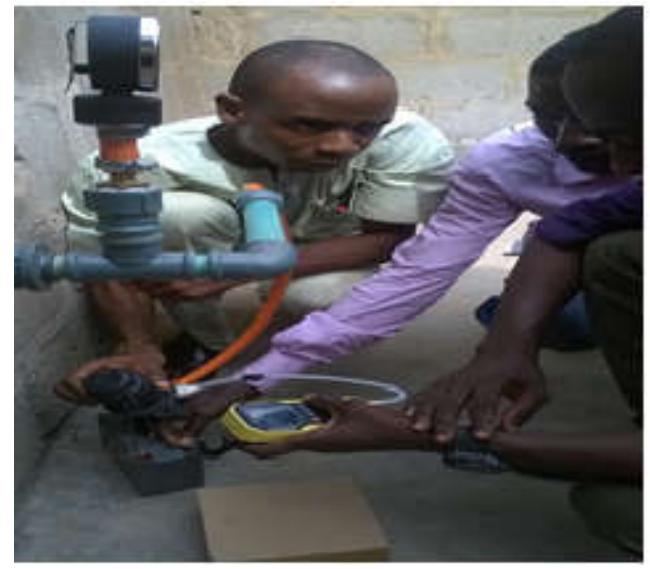

Plate 2: Digital gas detector being used forbiogas analysis

Procedures for Chemical and Microbial Analysis of Slurry Samples: The following chemical parameters were determined in the laboratory from the samples of digestrate and effluent slurries: nitrogen, phosphorus, potassium, calcium, $\mathrm{C}$ : $\mathrm{N}$ ratio, organic matter, sodium, magnesium, iron, lead, copper, zinc and cadmium according to Anon, 1992; APHA, 1998; AOAC, 2002; APHA, 2005. The microbial analysis of influent and effluent samples were carried out using multiple fermentation method to estimate the most probable number (MPN) of coliform organism in 100 $\mathrm{ml}$ of sample for diagnosis of bacteriological contamination according to Tillet et al., 1987 and Senior, 1996.

Determination of Biogas Composition and Volume: Biogas produced was analyzed using EXIBD-1 MultiGas Analyzer. The gas detector was used to determine the concentrations of $\mathrm{CO}, \mathrm{CO}_{2}, \mathrm{CH}_{4}$, and $\mathrm{H}_{2} \mathrm{~S}$ in the biogas.

\section{RESULTS AND DISCUSSION}

Chemical and Microbial Analysis of Well Water and Feedstock Materials before Co-digestion: The results of chemical and microbial assessment of the well water used for mixing feed stock materials (cow dung, cow intestinal waste and mixed organic waste) before co-digestion with faecal sludge are shown in Tables 1 and 2 .

The levels of chemical contents in the well water were generally low and within the WHO standard limits. This gave a clear indication that the well water in the household was not contaminated. The results are; $\mathrm{pH}$ $(6.8 \pm 0.12)$, conductivity $(243 \pm 1.03 \mu \mathrm{S} / \mathrm{m})$, Total volatile solids $(0.005 \pm 0.001 \mathrm{mg} / \mathrm{l})$. Fixed Dissolved solids $(0.0009 \pm 0.0002 \mathrm{mg} / \mathrm{l})$, Total solids $(138 \pm 1.4$ $\mathrm{mg} / \mathrm{l})$, TDS $(133 \pm 1.1 \mathrm{mg} / \mathrm{l})$, Nitrate $(0.1 \pm 0.12 \mathrm{mg} / \mathrm{l})$, Sulphate $(0.2 \pm 0.13 \mathrm{mg} / \mathrm{l})$, Phosphate $(0.47 \pm 0.4 \mathrm{mg} / \mathrm{l})$, $\mathrm{Pb}(0.01 \pm 0.001 \mathrm{mg} / \mathrm{l}), \mathrm{Cu}(0.01 \pm 0.001 \mathrm{mg} / \mathrm{l}), \mathrm{Cd}$

SOYINGBE, AA; OLAYINKA, O; BAMGBOSE, O; ADETUNJI, MT 
$(0.01 \pm 0.001 \mathrm{mg} / \mathrm{l}), \mathrm{Zn}(1.2 \pm 0.1 \mathrm{mg} / \mathrm{l})$, D.O (5.82 \pm 0.2 . $\mathrm{mg} / \mathrm{l})$, BOD $(18.2 \pm 1.1 \mathrm{mg} / \mathrm{l}), \mathrm{COD}(26 \pm 1.3 \mathrm{mg} / \mathrm{l})$, E.Coli $(0 \mathrm{cfu} / 100 \mathrm{ml})$, Total viable count $\left(1.0 \times 10^{-}\right.$ $\left.{ }^{3} \pm 0.07 \mathrm{cfu} / 100 \mathrm{ml}\right)$ and Salmonella $(0 \mathrm{cfu} / 100 \mathrm{ml})$. In comparing the nutrient content of the feedstock materials, all chemical nutrients, including Nitrogen, Phosphorus, Potassium, Carbon, Magnesium and Calcium were higher in mixed organic waste except for total volatile solids which was higher in Cow Intestinal Waste. The reason could probably be traced to varieties of proteineous and nutrient rich organic materials, including food remnants, fruits, vegetable and so on that made up the mixed organic waste. The high content of total volatile solids in Cow Intestinal Waste and cow dung is an indication of their relative amount of organic matter and biochemical stability. The results of heavy metals were lead $(\mathrm{mg} / \mathrm{l}): 12 \pm 0.3$, $17 \pm 1.1,13.5 \pm 0.3$; Cadmium (mg/l): $4.5 \pm 0.2,1.1 \pm 0.1$, $3.5 \pm 0.3 ; \operatorname{Zinc}(\mathrm{mg} / \mathrm{l}): 26.2 \pm 1.2,47.8 \pm 0.91,52 \pm 3.3$; Iron $(\mathrm{mg} / \mathrm{l}): 19 \pm 1.3,12.6 \pm 0.11,10 \pm 1.3 ; \mathrm{Nickel}(\mathrm{mg} / \mathrm{l})$ : $5.4 \pm 0.1,6.7 \pm 0.31,7.8 \pm 0.11$; Chromium (mg/l) : $6.7 \pm 0.4,7.4 \pm 0.22,15.4 \pm 0.42$ for Cow Dung, Cow
Intestinal Waste and Mixed Organic Waste respectively.

\begin{tabular}{|c|c|}
\hline Parameters & Mean \pm SD \\
\hline $\mathrm{pH}$ & $6.8 \pm 0.12$ \\
\hline Conductivity ( $\mu \mathrm{S} / \mathrm{m})$ & $243 \pm 1.03$ \\
\hline Total Volatile Solids (mg/) & $0.0 \overline{5} \pm 0.001$ \\
\hline Fixed Digsolved solids (mg/l) & $0.009 \pm 0.002$ \\
\hline Total Solids (mg/l) & $138 \pm \overline{1.4}$ \\
\hline $\operatorname{TDS}(\mathrm{mg} / \mathrm{l})$ & $133 \pm 1.1$ \\
\hline Nitrate $(\mathrm{mg} / \mathrm{l})$ & $0.1 \pm 0.12$ \\
\hline Sulphate (mg/l) & $0.2 \pm 0.13$ \\
\hline Phosphate (mg/l) & $0.4 \overline{7} \pm 0.4$ \\
\hline $\mathrm{Ph}(\mathrm{mg} / \mathrm{l})$ & $0.01 \pm 0.001$ \\
\hline $\mathrm{Cu}(\mathrm{mg} / \mathrm{l})$ & $0.01 \pm 0.001$ \\
\hline $\mathrm{Cd}(\mathrm{mg} / \mathrm{l})$ & $0.01+0.001$ \\
\hline $\mathrm{Zn}(\mathrm{mg} / \mathrm{l})$ & $1.2 \pm 0.1$ \\
\hline D.O $(\mathrm{mg} / \mathrm{l})$ & $5.8 \overline{2} \pm 0.2$ \\
\hline $\mathrm{BOD}(\mathrm{mg} / \mathrm{l})$ & $18.2 \pm 1.1$ \\
\hline $\mathrm{COD}(\mathrm{mg} / \mathrm{l})$ & $26 \pm 1.3$ \\
\hline E.Coli (cfiul $100 \mathrm{ml})$ & \\
\hline Total viable count (cfiv/ $100 \mathrm{ml}$ ) & $1.0 \times 10^{-3} \pm 0.07$ \\
\hline Salmonella $(\mathrm{cfi} / 100 \mathrm{ml})$ & \\
\hline
\end{tabular}

Table 2: Chemical Composition of Feedstock materials before co-digestion.

\begin{tabular}{|c|c|c|c|}
\hline Parameters (mg/l) & COW Dung (CD) & $\begin{array}{l}\text { COW Intestinal } \\
\text { Waste (CIW) }\end{array}$ & $\begin{array}{l}\text { Mixed Organic } \\
\text { Waste (MOW) }\end{array}$ \\
\hline C (\%) & $7.5 \pm 1.10$ & $6.3 \pm 0.30$ & $36.6 \pm 0.10$ \\
\hline $\mathrm{N}(\%)$ & $0.25 \pm 0.20$ & $0.2 \overline{7} \pm 0.30$ & $2.5 \pm 0.12$ \\
\hline $\mathrm{C}: \mathrm{N}$ & $30: 1^{-}$ & $23: 1^{-}$ & $15: \overline{1}$ \\
\hline P (\%) & $0.2 \pm 0.01$ & $0.1 \pm 0.01$ & $5.7 \pm 0.02$ \\
\hline $\mathrm{K}(\%)$ & $0.4 \pm 0.10$ & $0.3 \pm 0.01$ & $8.4 \pm 0.20$ \\
\hline $\mathrm{Mg}(\%)$ & $0.7 \pm 0.10$ & $0.9 \pm 0.20$ & $11 . \overline{2} \pm 0.12$ \\
\hline $\mathrm{Ca}(\%)$ & $2.02 \pm 1.11$ & $1.4 \pm 1.10$ & $4.5 \pm \overline{1} .21$ \\
\hline TDS (mg/l) & $68 \pm 0.30$ & $73 . \overline{5} \pm 0.50$ & $62 . \overline{4} \pm 0.11$ \\
\hline FDS $(\mathrm{mg} / \mathrm{l})$ & $24.2 \pm 0.12$ & $20.3 \pm 0.40$ & $25.6 \pm 0.21$ \\
\hline $\mathrm{DO}(\mathrm{mg} / \mathrm{l})$ & $3.01 \pm 1.10$ & $2.53 \pm 1.21$ & $2.84 \pm 1.91$ \\
\hline $\mathrm{BOD}(\mathrm{mg} / \mathrm{l})$ & $221 \overline{4}+1.30$ & $2189 \pm 1.32$ & $2204+1.20$ \\
\hline $\operatorname{COD}(\mathrm{mg} / \mathrm{l})$ & $9364 \pm 1.40$ & $9210 \pm 1.32$ & $9284 . \overline{5} \pm 1.21$ \\
\hline $\mathrm{Pb}(\mathrm{mg} / \mathrm{l})$ & $12.3 \pm 0.30$ & $17 \pm 1.10$ & $13.5 \pm 0.30$ \\
\hline $\mathrm{Cd}(\mathrm{mg} / \mathrm{l})$ & $4.5 \pm \overline{0} .20$ & $1 . \overline{1}+0.10$ & $3.5 \pm \overline{0} .33$ \\
\hline $\mathrm{Zn}(\mathrm{mg} / \mathrm{l})$ & $26 . \overline{2}+1.20$ & $47 . \overline{8}+0.91$ & $52 \pm 3.31$ \\
\hline $\mathrm{Fe}(\mathrm{mg} / \mathrm{l})$ & $19+1.30$ & $12.6 \pm 0.11$ & $10 \pm 1.32$ \\
\hline $\mathrm{Ni}(\mathrm{mg} / \mathrm{l})$ & $5 . \overline{4} \pm 0.10$ & $6.7 \pm 0.31$ & $7 . \overline{8}+0.11$ \\
\hline $\mathrm{Cr}(\mathrm{mg} / \mathrm{l})$ & $6.7 \pm 0.40$ & $7.4 \pm 0.22$ & $15 . \overline{4} \pm 0.42$ \\
\hline E.Coli (cfu / 100 ml) & $1.4 \times 10^{5} \pm 0.12$ & $1.5 \times 10^{5} \pm 0.32$ & $1.3 \times 10^{5} \pm 0.11$ \\
\hline Salmonella (cfu/ $100 \mathrm{ml}$ ) & $1.0 \times 10^{5} \pm 0.21$ & $1.2 \times 10^{5} \pm 0.51$ & $1.1 \times 10^{5} \pm 0.14$ \\
\hline Bacillus Cereus(cfu/ 100ml) & $1.3 \times 10^{4} \pm 0.32$ & $1.7 \times 10^{4} \pm 0.13$ & $1.4 \times 10^{4} \pm 0.41$ \\
\hline Total Count(cfu / $100 \mathrm{ml})$ & $1.1 \times 10^{7} \pm 0.14$ & $1.3 \times 10^{7} \pm 0.45$ & $1.0 \times 10^{7} \pm 0.16$ \\
\hline
\end{tabular}

The Cow Intestinal Waste had highest lead concentration and lowest Cadmium concentration among the feedstock materials. Microbial population was also prominent in all the feedstock materials. The $\mathrm{pH}$ of the well water was within the neutral limit. The result agreed to the findings of Bisi-Johnson et al., (2017) who reported $\mathrm{pH}$ range of 6.4 - 7.6 during evaluation of physico-chemical and microbial qualities of source and stored household waters in some communities in South Western Nigeria using standard methods. It also conforms to findings of pervious researchers (Ikem et al., 2002; Longe et al., 2010 and Soyingbe et al., 2014), but disagreed with the $\mathrm{pH}$ values of 5.68-5.72 reported by Akinbile and Yusuff, (2011). Measurement of $\mathrm{pH}$ is essential for the understanding of water chemistry processes, such as acid-base chemistry, alkalinity, neutralization, biological stabilization, precipitation, coagulation disinfection, and corrosion control (APHA, 2005). The mean total dissolved solid (TDS) of the well water sample was $133 \pm 1.1 \mathrm{mg} / 1$ which was below the WHO limit $(1000 \mathrm{mg} / \mathrm{l})$. This result agreed with the findings 
of Akinbile et al., (2011). Nitrate, the most highly oxidized form of nitrogen compound is commonly presented in surface and groundwater because it is the end product of aerobic decomposition of organic nitrogenous matter. Unpolluted natural waters usually contains only minute of qualities of nitrate. The nitrate value of this work was below WHO recommended limit of $50 \mathrm{mg} / \mathrm{l}$. Nitrate concentration above the recommended value of $10 \mathrm{mg} / \mathrm{l}$ is dangerous to pregnant woman and poses a serious health threat to infants less than three to six months of age because of its ability to cause methaemoglobinaemia or blue baby syndrome in which blood loses its ability to carry sufficient oxygen (Frecham et al., 1986). The nitrate value obtained is far below the values reported by Malomo et al., (1990) who gave nitrate concentration of up to $124 \mathrm{mg} / \mathrm{l}$ in shallow groundwater near pollution source in Southwest, Nigeria. The sulphate content was within the WHO limit of $250 \mathrm{mg} / 1$ and could be utilized in fisheries project and agricultural activities. According to Esry et al., (1991) the levels of sulphate above $600 \mathrm{mg} / \mathrm{l}$ act as purgative in humans. All the heavy metals analyzed were within the WHO standard limit. Though, zinc is an essential element needed by the body and is commonly found in nutritional supplements and all foods. However, when taken in relatively large quantity over a period of time, zinc affects human health (Sangodoyin, 1991). A similar result was reported by Igbinosa and Okoh, (2009) and the result obtained in this study was in agreement with the findings of Ikem et al., (2002) and Shyamala et al., (2008). The microbial quality of the well water was satisfactory because E.coli and salmonella species that are major indicators of water pollution were not detected. Coliform populations are indicators for pathogenic organisms. They should not be found in drinking water but usually present in surface water, boil and feces of human and animals. Absence of coliform population in the water sample is a clear indication of good sanitary condition in the study area. However, this result disagreed with BisiJohnson et al., (2017) who observed higher mean values of total coliform and E.coli in stored water during evaluation of physico-chemical and microbial qualities of source and stored household waters in some communities in South Western Nigeria. Though very little information was available on analysis of faecal sludge in Nigeria, the values obtained for the feedstock materials before co-digestion with faecal sludge showed higher nutrient composition when compared with a similar study carried out on mixture of cow dung and water hyacinth by Sridhar et al., (2014). The nutrient value obtained for the feedstock materials of Nitrogen ranged from $(0.25-0.27 \%)$, phosphorus $(0.2-5.7 \%)$ and potassium $(0.3-8.4 \%)$ were higher than $\mathrm{N}(0.2 \%), \mathrm{P}(0.3 \%)$ and $\mathrm{K}(0.7 \%)$ obtained by Sridhar et al., (2014). This result supported the Moller and Muller, (2012) who stated that the nutrient content of bio-slurry will be more or less the same as that of the manure that is used as feedstock. However, because part of the organic matter is decomposed during the digestion process, the nutrient content will be higher in the bio-slurry than that in the manure. Also, because of the breakdown of organic matter during digestion, organically bound nutrients are mineralized into a directly available form. Anaerobic digestion tends to increase the content of available nitrogen, in the form of ammonium-nitrogen. Moller and Muller (2012) also reported $45-80 \%$ increase in nitrogen concentrations in anaerobically digested materials for biogas production. This result also corroborated to the findings of Gurung, (1997) in terms of nitrogen content but differs in phosphorus and potassium. He reported that nitrogen levels in digested manure were about 2-2.5 times higher than in undigested farmyard manure while phosphorus and potassium remained the same after anaerobic digestion. This result agreed with the findings of Den Toom, (2013) who reported N (0.24-0.26\%), P (0.3-2.8\%) and K (0.3-1.4\%) during biodegradation of Cow dung, Cow intestinal waste and poultry waste for biogas production. This result disagreed with the findings of Smith, (2013) who observed decrease in the concentrations of nitrogen, phosphorus and potassium in the slurry produced from the mixture of mixed organic waste and faecal sludge for biogas generation for electricity supply. In terms of gas composition, methane formed the largest component of the biogas produced by all the substrates (Figure 2). There was no hydrogen sulphide in the gas produced by Faecal Sludge + Cow Intestinal Waste. The highest percentage of methane was found in Faecal Sludge + Cow Intestinal Waste produced biogas while Faecal Sludge Only produced the gas with the least percentage of methane and highest percentages of $\mathrm{CO}_{2}$ and $\mathrm{CO}$. This result agreed with the findings of Wei et al., (2011) who reported an increasing trend of biogas production from commencement and a drop after 300 days from supernatants of hydrothermally treated municipal sludge by up-flow anaerobic sludge blanket reactor. Alkan-Ozkaynak and Karthikayan,(2011) also reported a high rate of biogas production from treated thin sullage with a drop towards the end of the experiment. Similarly, the finding was in agreement with Dahunsi and Oranusi, (2013), who reported steady increase rate of biogas production from ninth day to a peak on the twenty third day before dropping. Laskri and Nedjah, (2015) reported that the volume of gas produced by anaerobic digestion of wastewater sludge is ten times more than the experience of the anaerobic digestion of organic wastes from the 
landfill. Furthermore, Rabah et al., (2010) also reported a highest volume of biogas $\left(2240 \mathrm{~cm}^{3}\right)$ in week 2 while the least volume $\left(1820 \mathrm{~cm}^{3}\right)$ was obtained in week 4 of their work on assessment of biogas production using abattoir waste at different retention time. According to Sridhar et al.,(2016), biogas is chiefly methane (60-70\%) and carbon dioxide (30-40\%). Occasionally, other gases such as hydrogen $(5-10 \%)$, nitrogen (1-2\%), and hydrogen sulphide $(<1 \%)$ may be found depending on the nature of raw materials and operating conditions. The level of methane obtained in this study $(70 \%)$ was quite a good indication that the mixture of faeces, vegetable waste, faeces and cow dung forms suitable recipe for biogas generation. The level of methane was similar to 70.6 $\%$ of methane evolved from the mixture of pig dung and selected crop waste in a study conducted by Okareh et al., (2012). Good performance of the digester in terms of methane generation could be explained by air tight condition of the digester that was ensured during the construction. The composition of methane gas generated from the mixture was higher than $58 \% \mathrm{CH}_{4}$ and $24 \% \mathrm{CO}_{2}$ obtained by Dahunsi and Oranusi (2013). It was also higher than the levels found in other previous studies: Lawbuary (2006) $\left(\mathrm{CH}_{4}: 58 \%\right.$ and $\left.\mathrm{CO}_{2}: 15-35 \%\right)$, Mathias (1998) $\left(\mathrm{CH}_{4}: 65-70 \%\right.$, and $\left.\mathrm{CO}_{2}: 42 \%\right)$ and Smith (1993) $\left(\mathrm{CH}_{4}: 55-70 \%\right.$ and $\left.\mathrm{CO}_{2}: 30-45 \%\right)$.

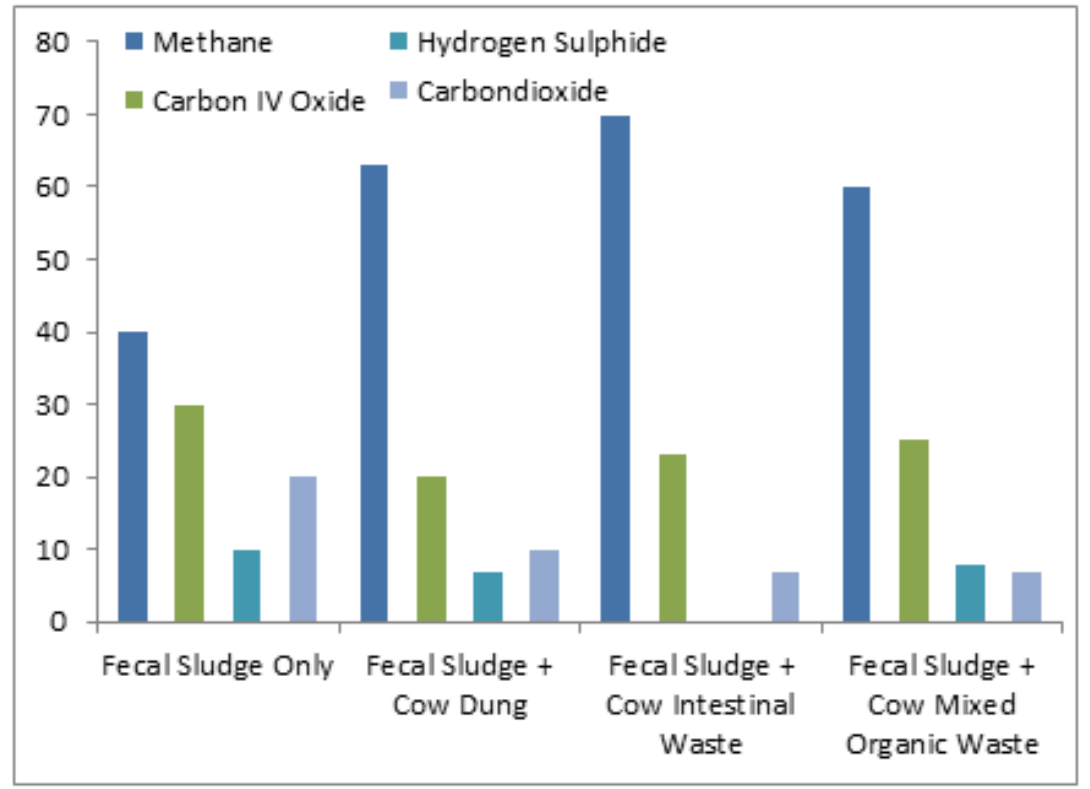

Fig 4: Composition of biogas generated from the digester

Chemical Characteristics of the bio slurry produced after co-digestion of faecal sludge with the feedstock materials: Table 3 shows the results of chemical characteristics of the bio-slurry produced after codigestion of faecal sludge with the feedstock materials during anaerobic gas production in the digester. The levels of macronutrients were; carbon: $(5.0 \pm 0.1 \%)$, nitrogen $(0.41 \pm 0.1 \%)$, phosphorus $(0.13 \pm 0.1 \%)$, potassium $(0.12+0.1 \%)$ for faecal sludge only; carbon $(6.0 \pm 1.01 \%)$, nitrogen $(0.42 \pm 0.1 \%)$, phosphorus $(0.2 \overline{4} \pm 0.11 \%)$, potassium $(0 . \overline{3} \pm 0.12 \%)$ for faecal sludge + Cow Dung; carbon $(5.3+0.11 \%)$, nitrogen $(0.36 \pm 0.1 \%)$ phosphorus $(0.11 \pm 0.02 \%)$, potassium $(0.4 \pm 0.1)$ for faecal sludge + cow intestinal waste; carbon $(5.8+0.11 \%)$, nitrogen $(0.46 \pm 0.1 \%)$, phosphorus $(0.15+0.1 \%)$, potassium $(0.1 \pm 0.1 \%)$ for faecal sludge + mixed organic waste. Carbon and organic matter were found to be higher in all the slurries produced. The slurry produced by faecal sludge only had lowest $\mathrm{C}: \mathrm{N}$ of 12: 1 while that of faecal sludge + cow intestinal waste had highest $\mathrm{C}: \mathrm{N}$ of $15: 1$. The mean carbon content of the faecal sludge only, produced slurry was $5.0 \pm 0.1 \%$ and for the three feedstock materials ranged from $5.3 \pm 0.11$ to $6.0 \pm 1.01$ $\%$. The nitrogen content of the bio slurries ranged from $0.36 \pm 0.10$ to $0.46 \pm 0.1$ with faecal Sludge + mixed organic waste had highest value. For heavy metals concentration in the slurries, faecal sludge + cow intestinal waste slurry showed the highest concentration of Zinc which was $16.8+0.34 \mathrm{mg} / 1$ while the slurry from FSO showed lowest concentration of Chromium $(0.1 \pm 0.01 \mathrm{mg} / \mathrm{l})$. Similarly, for microbial contents of the slurries, FSO slurry had lowest total count of bacteria of $1.2 \times 10^{-2} \pm 0.01 \mathrm{cfu} / \mathrm{ml}$ with E. Coli $\left(1.1 \times 10^{-2} \pm 0.12 \mathrm{cfu} / 100 \mathrm{ml}\right)$, salmonella $\left(2.0 \times 10^{-2} \pm\right.$ $\left.0.02) \mathrm{cfu}^{-} 100 \mathrm{ml}\right)$, and Bacillus cereus $\left(2.5 \times 10^{-}\right.$ 
$\left.{ }^{2} \pm 0.32 \mathrm{cfu} / 100 \mathrm{ml}\right)$. The populations of the microbes in all the slurries were significantly lower. The primary nutrients required by microorganisms for growth are: $\mathrm{C}, \mathrm{N}, \mathrm{P}$, and $\mathrm{K}$ (Tchobanoglous et al, 1993). The $\mathrm{C}$ and $\mathrm{N}$ play the most important role in the composting process: $\mathrm{C}$ is used by microorganisms for energy and growth while $\mathrm{N}$ is needed for protein and production (Metcalf and Eddy, 2003). It was also observed that the nutrient values ( $\mathrm{N}$ and $\mathrm{K}$ ) in cow intestinal waste (CIW) fed into the digester as influent was lower than the bio-slurry sample produced after mixing with faecal sludge in the digester, but was reverse for mixed organic waste (MOW) influent and its slurry produced after mixing with faecal sludge in the digester. The result of organic waste decomposition inside a biogas digester was stabilization of organic waste whereby the waste was broken down to stable elements. These elements increases in quantity as decomposition progresses to maturity, leading to more values observed in the spent slurry of cow intestinal waste mixed with faecal sludge. A number of studies have demonstrated apparently significant changes in slurry composition following anaerobic digestion (Hobson et al., 1974; Baldwin 1993). The results of some early research in Germany showed a small reduction in slurry solids content, a decline in organic $\mathrm{N}$ content and an increase in $\mathrm{NH}_{4}-\mathrm{N}$ content (from $50 \%$ to about $60 \%$ of total $\mathrm{N}$ ) (Vetter et al.,1987). The nutrient values of the bioslurries in this study were a little bit lower compared to work of AminuHaque, (2013) who reported the value range of digested bio-slurry of $\mathrm{N}$ (1.40-1.80\%), $\mathrm{P}(1.10-2.00 \%)$ and $\mathrm{K}(0.80-1.20)$ during comparison of digested bio-slurry nutrient values to other organic fertilizers and also Gurung, (1997) who reported N (3.0-5.0\%), P (2.5 - 4.4\%) and $\mathrm{K}(0.7-1.9 \%)$ in spent slurry from night soil biogas plant. The nutrient levels obtained were close to the standards established by National Special Programme on Food Security: Nitrogen (1.0 to 4.0\%); Phosphorus (1.5 to 3.0) and Potassium (1.0 to $1.5 \%$ ) (Soyingbe, et al., 2012). They also have the primary characteristics of organic fertilizer under specification of the compost quality standard in Thailand which stated the following; organic carbon, $>17.4 \%$; Nitrogen $\geq 1.0$; Phosphorus, $\geq 0.44$ and Potassium, $\geq 0.5 \%$ (Soyingbe et al., 2012).

\begin{tabular}{|c|c|c|c|c|}
\hline Parameters & $\begin{array}{l}\text { Faecal Sludge } \\
\text { Only } \\
\text { (FSO) }\end{array}$ & $\begin{array}{l}\text { Faecal Sludge }+ \\
\text { Cow Dung } \\
(\mathrm{FS}+\mathrm{CD})\end{array}$ & $\begin{array}{l}\text { Faecal Sludge }+ \\
\text { Cow Intestinal } \\
\text { Waste (FS+CIW) }\end{array}$ & $\begin{array}{l}\text { Faecal Sludge }+ \\
\text { Mixed Organic } \\
\text { Waste (FS+MOW) }\end{array}$ \\
\hline $\mathrm{C}(\%)$ & $5.0 \pm 0.1$ & $6.0 \pm 1.01$ & $5.3 \pm 0.11$ & $5.8 \pm 0.11$ \\
\hline N (\%) & $0.4 \overline{1} \pm 0.1$ & $0.4 \overline{2} \pm 0.1$ & $0.3 \overline{6} \pm 0.1$ & $0.4 \overline{6} \pm 0.10$ \\
\hline $\mathrm{P}(\%)$ & $0.13 \pm 0.1$ & $0.24 \pm 0.11$ & $0.11 \pm 0.02$ & $0.15 \pm 0.1$ \\
\hline K $(\%)$ & $0.12 \pm 0.1$ & $0.3 \pm 0.12$ & $0.4 \pm 0.1$ & $0.1 \pm \overline{0} .1$ \\
\hline $\mathrm{C}: \mathrm{N}$ & $12: 1 \pm 0.2$ & $14: \overline{1} \pm 0.1$ & $15: \overline{1} \pm 0.11$ & $13: \overline{1} \pm 0.21$ \\
\hline Organic Matter (\%) & $12.7 \pm 0.1$ & $28.9 \pm 1.0$ & $32.2 \pm 0.12$ & $29.5 \pm 0.3$ \\
\hline $\operatorname{Mg}(\mathrm{mg} / \mathrm{l})$ & $0.91 \pm 1.1$ & $1.2 \pm 0.1$ & $1.3 \pm \overline{0} .2$ & $1.1 \pm \overline{0} .11$ \\
\hline $\mathrm{Ca}(\mathrm{mg} / \mathrm{l})$ & $2.01 \pm 0.1$ & $2.3 \overline{5} \pm 1.2$ & $1.6 \pm 0.4$ & $1.3 \overline{6} \pm 1.3$ \\
\hline $\mathrm{BOD}(\mathrm{mg} / \mathrm{l})$ & $1,12 \overline{0} \pm 1.4$ & $998 \pm 1.11$ & $968 \pm 1.01$ & $1,00 \overline{3} .5 \pm 1.02$ \\
\hline $\mathrm{COD}(\mathrm{mg} / \mathrm{l})$ & $6,123 \pm 2.1$ & $7,69 \overline{3} \pm 1.41$ & $6,8 \overline{9}+1.16$ & $7,101 \pm 1.21$ \\
\hline $\mathrm{Pb}(\mathrm{mg} / \mathrm{l})$ & $1.14 \pm 0.1$ & $4.1 \pm 0.12$ & $3.5 \pm 0.13$ & $2.1 \pm 0.14$ \\
\hline $\mathrm{Cd}(\mathrm{mg} / \mathrm{l})$ & $0.25 \pm 0.1$ & $1.2 \pm 0.01$ & $0.6 \pm 0.01$ & $1.1 \pm 0.11$ \\
\hline $\mathrm{Zn}(\mathrm{mg} / \mathrm{l})$ & $9.1 \pm 0.11$ & $12 . \overline{7} \pm 1.11$ & $16 . \overline{8}+0.34$ & $15.2 \pm 0.15$ \\
\hline $\mathrm{Fe}(\mathrm{mg} / \mathrm{l})$ & $10 \pm 0.12$ & $6 \pm 0 . \overline{1} 5$ & $5.2 \pm \overline{0} .21$ & $4.5 \pm \overline{0} .14$ \\
\hline $\mathrm{Ni}(\mathrm{mg} / \mathrm{l})$ & $1 . \overline{6}+0.11$ & $1 . \overline{2} \pm 0.13$ & $2.1 \pm 0.14$ & $3.5 \pm 0.52$ \\
\hline $\mathrm{Cr}(\mathrm{mg} / \mathrm{l})$ & $0.1 \pm 0.01$ & $0.1 \pm 0.21$ & $1.9 \pm 0.01$ & $3.2 \pm 0.02$ \\
\hline Total Count (cfu / 100 ml) & $1.2 \times 10^{-2} \pm 0.01$ & $1.3 \times 10^{-2} \pm 0.04$ & $2.2 \times 10^{-2} \pm 0.03$ & $3.2 \times 10^{-2} \pm 0.03$ \\
\hline E.Coli $(\mathrm{cfu} / 100 \mathrm{ml})$ & $1.1 \times 10^{-2} \pm 0.12$ & $1.5 \times 10^{-2} \pm 0.03$ & $1.3 \times 10^{-2} \pm 0.02$ & $1.1 \times 10^{-2} \pm 0.02$ \\
\hline Salmonella (cfu/ $100 \mathrm{ml})$ & $2.0 \times 10^{-2} \pm 0.02$ & $1.1 \times 10^{-2} \pm 0.05$ & $1.2 \times 10^{-2} \pm 0.01$ & $1.3 \times 10^{-2} \pm 0.12$ \\
\hline Bacillus Cereus (cfu/ $100 \mathrm{ml}$ ) & $2.5 \times 10^{-2} \pm 0.32$ & $1.3 \times 10^{-2} \pm 0.01$ & $1.5 \times 10^{-2} \pm 0.04$ & $1.6 \times 10^{-2} \pm 0.03$ \\
\hline
\end{tabular}

The analysis of the feedstocks before and after anaerobic digestion revealed that there was a reduction in Biochemical Oxygen Demand (BOD) and Chemical Oxygen Demand (COD) indicating that anaerobic digestion was a viable way of reducing these parameters from sludge or wastewater. The reduction in Biochemical Oxygen Demand recorded in this study agreed with House,(2007) who reported that treating human waste through anaerobic digestion is a credible ethical sanitation technology and removes biochemical oxygen demand from sewage, conserves nutrients (especially nitrogen compounds) and most importantly reduces pathogens. Similarly, the reduction in chemical oxygen demand was in agreement with Wei et al., (2011) who reported a high chemical oxygen demand removal from supernatant of hydrothermally treated municipal sludge by up-flow anaerobic sludge blanket reactor (VASD). Also Yoneyamaet al., (2006) reported chemical oxygen demand removal rate reaching up to $75.9 \%$ during recovery of bioenergy from hydrothermally heated cow manure. Dahunsi and Oranusi, (2013) also observed drastic reduction of BOD, COD and ash contents of the biogas feedstock before and after 
anaerobic digestion of food waste and human excreta. The optimum carbon to nitrogen ratios in anaerobic digesters are between 20:1 and 30:1. A high $\mathrm{C}: \mathrm{N}$ is an indication of a rapid consumption of nitrogen by the methanogens and results in a lower gas production. On the other hand, a lower $\mathrm{C}$ : $\mathrm{N}$ causes ammonia accumulation and $\mathrm{pH}$ values exceeding 8.5 which are toxic to methanogenic bacteria. The values obtained for $\mathrm{C}: \mathrm{N}$ for the feedstock materials before digestion was in agreement with the optimum of between 20 and 30 for biogas generation from biomes. This agreed with the reported work of Ojikutu and Osokoya, (2014) who reported a $\mathrm{C}: \mathrm{N}$ of between $37: 1$ and $46: 1$ for four feedstock materials in evaluation of biogas production from food waste. Similar trend was also observed by Dahunsi and Oranusi (2013). Optimum C: $\mathrm{N}$ of the feedstock materials can be achieved by mixing waste of low and high $\mathrm{C}$ : $\mathrm{N}$ such as organic solids waste mixed with sewage or animal manure (Kim et al., 2006). The C: $\mathrm{N}$ of the bio-slurries formed in this study agreed with 10 to $15 \mathrm{C} / \mathrm{N}$ of National minimum Quality Standards for Compost and $(\mathrm{C} / \mathrm{N}$ $(\leq 20)$ of quality standard in Thailand (TACFS, 2005). In terms of heavy metals composition, higher values were also observed in the feedstocks and the slurries produced when mixed with feces than the mixture of water hyacinth and cow dung by Sridhar et al., (2014). The reason for high heavy metals composition in human faeces could be due to the fact that human beings are omnivorous animals while cattle are herbivorous animal that feed only on grass. Similarly, exposure to heavy metals would be more in human being due to bio-concentration and bioaccumulation from varieties of food they consume. The extensive studies by Kraus and Grammel, (1992) raised concern regarding the level of heavy metal in waste stream. This led to a gradual shutdown of municipal solid waste composting plants in Germany, Switzerland, Austria and France. High level of heavy metal may have potential effects on microorganisms inside the digester as well as quality of organic fertilizer produced from the spent slurry. However, the concentrations of heavy metals in the spent slurries were lower than the standards in some developed countries, including Germany, U S A and Canada (McGrath et al.,1994; Richards and Woodbury, 1992), indicating that the slurries are suitable for application on farms as organic fertilizer. Levels of heavy metals were significantly lower in bio-slurries produced than feedstocks with particular reference to iron, lead, copper, zinc and cadmium. Various studies have shown reduction in heavy metal levels during decomposition of organic waste (Ogunbanwo, 2001). Although, the exact mechanisms of these reduction are not known. It has been attributed to the metal ions becoming bound to organic molecules thereby reducing their solubility and therefore their polluting potential (Peter, 1993). Also, the values could be reduced if the community members separate their waste at households. Kraus and Wilke, (1997) examined compost made from non-source separated wastes and source separated waste i.e. wastes separated at household. He found out that the compost from source separated wastes contained, on average, $1 / 4$ the metal content of mixed waste compost. Comparison of microbial population in the feedstocks and the bio-slurries produced indicated a clear difference in the total counts. The total count of the feedstocks ranged from $1.0 \times 10^{7}$ to $1.3 \times 10^{7} \mathrm{cfu} / 100$ $\mathrm{ml}$ and $1.2 \times 10^{-2}$ to $3.2 \times 10^{-2} \mathrm{cfu} / 100 \mathrm{ml}$ for the bioslurries. The main reason for the reduction was very high temperature inside the digester which was always responsible for the death of microorganism. According to Lund et al., (1996) the average temperature within the digester remains about $40{ }^{\circ} \mathrm{C}$ above the ambient temperature. Microorganism such as coliform, salmonella and bacillus counts were also lower in the bio-slurries. The average total coliform count range $\left(1.2 \times 10^{-2}\right.$ to $\left.3.2 \times 10^{-2} \mathrm{cfu} / 100 \mathrm{ml}\right)$ found in the slurries was lower than the value $\left(3.5 \times 10^{11} \mathrm{cfu} / \mathrm{ml}\right)$ obtained in the slurry of pig dung mixed with crop waste in a study carried out by Okareh et al., (2012). The level of microbes was also lower than the standards stipulated by California Department of Resources Recycling and Recovery (CalRecycle), (2010) for fertilizer.

Conclusion: The study concluded that faecal sludge co-digested with various types of organic feedstock materials was effective in producing biogas and nutrient rich bio-slurries as organic fertilizer.

\section{REFERENCES}

Abubakar MM (1990). Biogas generation from animal wastes. Nigerian Journal Renewable Energy 5: 69-79

Adeniran, A.K; Ahaneku, I.E; Itodo, I.N; Rohjy, H.A (2014). Relative effectiveness of biogas production using poultry wastes and cow dung. AgricEngInt: CIGR Journal .16(1):126-132

Akinbile, C.O; Yusuff, M (2011). Assessment of groundwater quality near a Municipal Landfill in Akure, Nigeria. $2^{\text {nd }}$ international Conference on Environmental Science and Technology, IPCBE, 61, ACSIT Press, Singapore.

Alkan-Ozkaynak, A; Karthikayan, K.G (2011). Anaerobic digestion of thin sillage for energy recovery and water reuse in corn-ethanol plants. Bio-resources Technology.102 (21): $9891-9896$. 
American Public Health Association (APHA) (1998). Standard Method for the examination of Water and Wastewater.20 $0^{\text {th }}$ edition.Published jointly by American Water works Association and Water Environment Federation'. Washington, DC 20052605.

American Public Health Association/American Water Works Association/Water and Environment Federation Publication (APHA/AWWA/WEF) (2005).Standard Methods for the examination of water and wastewater.21st Edition. American Public Health Association, American Water Works Association, and Water and Environment Federation Publication. Washington D.C., USA. ISBN 0-87553-047-8.

Aminu-Haque, A.B.M (2013). Bioslurry, Ultimate choice of Bio-fertilizer, 2(4): 3-8

Anon, O (1992). Standard Methods of water and wastewater examination. $18^{\text {th }}$ Edition.American Public Health Association. NW. Washington. DC

Association of Official Analytical Chemists (2002). Official Methods of Analysis Association of Official Analytical Chemists, Maryland USA, $17^{\text {th }}$ Edition.

Baldwin, D.J (1993). Anaerobic digestion in the UK. A review of current practice. ETSU B/FW/00239REP. DTI Renewable Energy Research Programme.

Bisi-Johnson, M.A; Adediran, K.O; Akinola, S.A; Popoola, E.O.; Okoli, A.I (2017). Comparative physicochemical and microbiological qualities of source and stored household waters in selected communities in Southwestern Nigeria, Sustainability, 9: .454

Bitrus, R (2001). Design of An Anaerobic Bio-Reactor for the production of methane from Solid waste Organic Matter, Dept of Agricultural and Environmental Science River State.

California Department of Resources Recycling and Recovery (CalRecycle).2010, Compost Quality Standards in Organic Materials Management .http://www.calrecycle.ca.gov/Organics.

Cheremisinoff, NP (1980). Biomass Application. In: Technology and Production. Marcel DekkarInc, USA.
Dahunsi, 1. S. O; Oranusi I. U. S (2013) Co-digestion of Food Waste and Human Excreta for Biogas Production, British Biotechnology Journal 3(4): 485-499.

De Toom, R (2013). The effectiveness of bio-slurry as fertilizer. MSc thesis, Free University, Amsterdam, The Netherlands. 42.

Esrey, S.A; Potash, J.B; Shiff, C (1991). Effects of improved water supply and sanitation on ascariasis, diarrhea,

Drancunculiasis, hookworm infection, schistosomiasis and trachoma. Bulletin of the World Health Organization, 6(5): 609-621.

Frecham, R; Megarry, M; Mara, D (1986). Water Wastes and Health in Host Climates, Wiley and Sons, New York, 82.

Godi, N.Y; Zhengwuvi, L.B; Abdulkadir, S; Kamtu, P (2013). Effect of cow dung variety on biogas production, Journal of Mechanical Engineering Research., 5(1):1-4.

Guring J.B (1997). Review of Literature on Effects of Slurry use on Crop production, final report submitted to the Biogas Support program, Nepal.

Hobson, P.N; Bousfield, S; Summer, R (1974). The anaerobic digestion of organic matter, Critical Reviews in Environmental Control, 4:131-191.

Igbinosa, E.O; Okoh A.I (2009). Impact of discharge wastewater effluents on the physiochemical qualities of receiving watershed in a typical rural community, International Journal of Environmental Science and Technology, 6(2): 1735-1742.

Ikem, A; Osibanjo, O; Sridhar, M.K.C; Sobande, A (2002). Evaluation of Ground Water Quality Characteristics near Two waste Sites in Ibadan and Lagos, Nigeria. Water, Air, and soil Pollution. 174:307-333.

Kim, J.K; Oh, B.R; Chun, Y.N; Kim, S.W (2006). "Effects of temperature and hydraulic retention time on anaerobic digestion of food waste". Journal of Biology Science, 12(4):328-32.

Kraus, P; Wilke, M (1997). Contaminants in biocompost. Mull and Abfall4. (97): 211-219. 
Kraus, P; Grammel, U (1992). Relevance of contaminant discussion for bio-waste composting. Abfallwirtschaft, 9: 65-85.

Laskri, N; Nedjah, N (2015). Comparative study for Biogas production from different wastes.International Journal of Bio-Science and Bio-Technology.7 (4):39-46.

Lawbuary, J (2006). Biogas Technology in India: More than Ghandhi's Dream. HE20: Energy in Its Natural Environment Dissertation, New Delhi.

Li, R; Chen, S; Li, X (2009). Anaerobic co-digestion of kitchen waste and cattle manure production. Energy Sources. 31:1848-1856.

Longe, E.O; Balogun M.R (2010). Groundwater Quality Characteristics near a Municipal Landfill, Lagos, Nigeria, Research Journal of Applied Science, Engineering and Technology, 2(1): 3944.

Lopes, W.S; Leite, V.D; Parad, S (2004). Influence of innoculum performance on anaerobic reactors for treating municipal solid waste. Bioresource Technology, 94:261-266.

Lund, M.S; Andersen S.S; Torry-Smith, M (1996). 'Building of a flexibility Biogas Digester in Tanzania' Student Report, Technical University of Denmark, Copenhagen.

Malomo, S; Okufarasun, V.A; Oloeunnio, M.A; Omode, A.A (1990). Groundwater chemistry of weathered zone aquifers of an area underlain by basement complex rocks. Journal of African Earth Sciences, 11:357-371.

Mathaias G (1998). Biogas Technology- A Solution in Search of its problem. A case study of small scale rural development technology. Introduction and integration. Goteborg, Sweden.

McGrath, S. P; Chang, A; Page, A. L; Witter, E (1994). Land application of sewage sludge: scientific perspective of heavy metal load limits in Europe and United States. Environmental Revolution, 2: 108-118.

Metcalf, A; Eddy I.C (2003). Wastewater Engineering: Treatment and Reuse. New York, USA: McGraw-Hill. 4th edition. 1546 - 1554.

Moller, K; Muller, T (2012). Effects of anaerobic digestion on digestate nutrient availability and crop growth: A review. Engineering in Life Sciences 12(3): 242-257.

Ogunbanwo, A. O (2001). An assessment of the processes and operations of a pilot-scale organomineral fertilizer plant in a markert in Ibadan. MPH Project. Department of Epidemiology, Medical Statistics and Environmental Health.University of Ibadan.

Ojikutu, A.O; Osokoya, O.O (2014) Evaluation of biogas Production from food waste.The International Journal of Engineering and Science, 3:1-7.

Okareh, O.T; Adeolu, A.T; Shittu, O.I (2012). Enrichment of pig dung with selected crop wastes for the production of biogas. International Research Journal of Microbiology (IRJM), 3(7): 258-263.

Peter, B. W; (1993). Potential effect of heavy metals in municipal solid waste compost on plants and the environment. Biomass and Bioenergy 3. (3-4) :239-259.

Rabah, A.B; Baki, A.S; Hassan, L.G; Musa, M; Ibrahim A.D (2010). Production of biogas using abattoir waste at different times. Science World Journal, 5(4): 23-26.

Richards, T; Woodbury P (1992). The impact of separation of heavy metal contaminants in composts. Biomass and Bioenergy, 3: 195- 211.

Sangodoyin, A.Y (1991). Groundwater and Surface water pollution by Open Refuse dump

Senior, B.W (1996). Examination of water, milk, food and air. In Collee, J.G, Fraser, A.G, Marion, B.P, Simmons, A., editors. Mackie and McCartney,Practical medical microbiology, $14^{\text {th }}$ edition New York: Chuchill Living stone.883921.

Shyamala R; Shanti, M; Lalitha, P (2008). Physicochemical Analysis of Borewell Water Samples of Telunguapalayam Area in Coimbatire District, Tamilnadu, India, E-Journal of Chemistry, 5 (4): 924-929.

Smith, G (1993). Bio Energy System and the State of the Art Biogas Technology. Bio Energet Publishers, Bangkok, Thailand. 
Smith, J.U (2013). Potential of Small-Scale Biogas Digesters to Improve Livelihoods and Long Term Sustainability of Ecosystem Services in SubSaharan Africa, United Kingdom Aid, Aberdeen, United Kingdom.

Soyingbe, A.A; Hammed, T.B; Rosiji, C.O; Adeyemi, J.K (2012). Evaluation of fluted pumpkin (Telfairiaoccidentalis Hook) Stalk as Organic nutrient amendment in compost for its effective management and crop production.IOSR Journal of Environmental Science, Toxicology and Food Technology, 1(1):1-7.

Soyingbe, A.A; Salako, S.G; Hammed, T.B; (2014). Sanitary condition and characteristics of borehole water samples in Ogun State College of Health Technology, Ilese-Ijebu, Nigeria. African Journal of Environmental Health Science Volume No.(1), 57-63.

Sridhar, M. K. C; Coker, A. O; Hammed T. B; Oliyide A. (2014). Experiments on Co-Digestion of Cow Dung and Water Hyacinth (Eichhornia Crassipes) for Biogas Yield. International Journal of Sciences: Basic and Applied Research (IJSBAR) 15(1):16-24.

Sridhar, M. K. C; Hammed B; Taiwo, A; Okoye, O (Eds). (2016). Entrepreneurship in Waste Recycling, Book builders, Ibadan, Nigeria. 1-750

Tchobanoglous, G; Theisen, H; Vigil, S.A (1993). Integrated Solid Waste Management: Engineering, Principles and Management issues.McGraw-Hill International Editions, United State of America. USA, 135-146.
Thai Agricultural Commodity and Food Standard TACFS.2005. Compost national bureau of agricultural commodity and food standards. Bangkok, Thailand: Ministry of agriculture and cooperative.

www.acfs.go.th/standard/download/eng/compost .$/ p d f$.

Tillet, H.E (1987). Most probable number of organisms: Revised tables for multiple tube methods, Epidemiological Infections, 99: 9947199476.

Vetter, H; Steffens, G; Schropel, R (1987). The influence of different processing methods for slurry upon its fertilizer value on grassland.In HG Vamder<eer.Et a; (eds). Animal Manure on Grassland and Fodder Crops. Fertilizers or waste? MartinusNijoff, Dordrecht, 73-86.

Wei, Q; Chong, P; Wei, W; ZhongZhi, Z (2011). Biogas production from supernatant of hydrothermally treated municipal sludge by upflow anaerobic sludge blanket reactor. Bioresources Technology, 102 (21): 9904-9911.

Yoneyama, Y; Nishii, A; Nishimoto, M (2006). Upflow anaerobic sludge blanket (UASB) treatment of supernatant of cow manure by thermal pre-treatment. Water Science Technology s54 (9):221-227. 